\title{
POST-BANKRUPTCY INTEREST IN CHAPTER X REORGANIZATIONS*
}

INTEREST accruing after the commencement of reorganization proceedings, unlike that in ordinary bankruptcy, is not expressly treated by the governing statute. The original English practice, geared to efficient administration and equitable distribution of debtors' estates, generally denied post-petition interest. ${ }^{1}$ Otherwise, the courts reasoned, different rates attending claims of the same priority would give rise to a continuous change in creditors' ratable shares requiring a new basis of apportionment before every liquidating dividend. ${ }^{2}$ Prejudice to creditors whose claims carried comparatively low charges was apparently also feared. ${ }^{3}$ Codified in part by section sixty-three of the Bank-

*In re Inland Gas Corp., 241 F.2d 374, (6th Cir.), cert. denied, 355 U.S. 838 (1957).

1. Under English law, only interest to the date of the commission, i.e., petition, was allowed. Ex parte Bennet, 2 Atk. 527, 26 Eng. Rep. 716 (Ch. 1743); In re London, Windsor and Greenwich Hotels Co., [1892] 1 Ch. 639. Cf. In re Talbott, 39 Ch. D. 567 (1888). A similar practice is followed today. Bankruptcy Act, 1914, 4 \& 5 Gro. 5, c. 59, $\S 66$.

For general discussion of interest claims in insolvency and bankruptcy proceedings, see 3 Collier, Bankruptcy $\llbracket 63.16$ (14th ed. 1956) (hereinafter cited as Collier) ; Clark, Contingent and Inmature Claims in Receivership Proceedings, 29 YALE L.J. 481, 486-87 (1920); Hanson, Effect of Insolvency Proceedings on Creditor's Right to Interest, 32 MrCH. L. Rev. 1069 (1934); Note, 58 YaLE L.J. 982 (1949).

2. In re Kallak, 147 Fed. 276, 277-78 (D.N.D. 1906) ; Bromley v. Goodere, 1 Atk. 75, 79, 26 Eng. Rep. 49, 51 (Ch. 1743); see 3 Colnner \ 63.16; Note, 61 HARv. L. REv. 354 (1948).

3. Alluded to in an early English case, Bromley v. Goodere, supra note 2, at 79, 26 Eng. Rep. at 51, this rationale was clearly expounded in American Iron and Steel Mfg. Co. v. Seaboard Air Line Ry., 233 U.S. 261, 266 (1914). "If all claims were of equal dignity and all bore the same rate of interest, from the date of receivership to the date of final distribution, it would be immaterial whether the dividend was calculated on the basis of principal alone or of principal and interest combined. But some of the debts might carry a high rate and some a low rate, and hence inequality would result in the payment of interest which accrued during the delay incident to collecting and distributing the funds. As this delay was the act of law, no one should thereby gain an advantage or suffer a loss."

However, the court-imposed delay does not affect claimants whose interest-bearing debts are not due on the date of petition. For until their debts become due, their contractual disadvantage of a lower interest rate would continue, irrespective of delay caused by bankruptcy proceedings or any other external event. The English rule accordingly recognizes an exception for such creditors. See In re Browne \& Wingrove, [1891] 2 Q.B. 574 (C.A.) (allowing post-bankruptcy interest on debts not payable at date of petition). Section 63 (a) (1) of the American Bankruptcy Act provides for a rebate of unearned interest on debts not payable and not carrying interest at the time of bankruptcy. 30 STAT. 563 (1898), as amended, 11 U.S.C. § 103 (a) (1952).

Moreover, this rationale is accurate only if the rate of earnings of the debtor's estate during bankruptcy is lower than the highest interest charge. Otherwise, all creditors benefit by any delay. And, if denying interest protects low rate debts, it also penalizes high rate creditors. See Tredegar Co. v. Seaboard Air Line Ry., 183 Fed. 289 (4th Cir. 1910) (rule protects debtor while unable to use property). For application of the rule 
ruptcy Act, 4 the English rule has long been followed by American courts determining creditors' rights in ordinary bankruptcy. ${ }^{5}$ More recently, a congressional intent to equate tax claims with other debts for purposes of the rule was invoked by the Supreme Court to disallow, in ordinary bankruptcy, postpetition interest on taxes owed a municipality. ${ }^{6}$ Two years later, assuming that tax claims were to be accorded similar treatment in reorganizations under Chapter X, the Court affirmed an order denying interest in United States $v$. Edens. ${ }^{7}$ The English rule was thus employed even though post-bankruptcy

to contests between creditors of differing priorities, see The American Cas. Ins. Co.'s Case, 82 Md. 535, 34 Atl. 778 (1896); Annot., 69 A.L.R. 1210 (1930) (collecting cases). IBut see Spring Coal Co. v. Keech, 239 Fed. 48 (4th Cir. 1916).

4. 30 STAT. 562 (1898), as amended, 11 U.S.C. $\$ 103$ (1952). Section 63(a) (1) disallows post-petition interest on fixed liabilities absolutely owing at the filing date if evidenced by a judgment or an instrument in writing. Moreover, a rebate of interest is required on debts not payable as of that date and not providing for interest. See note 3 supra. Section 63(a) (5) compels a creditor of a provable debt reduced to judgment between the petition's filing and consideration of the bankrupt's application for discharge to deduct interest accruing between filing and entry of the judgment. Other claims, such as contract claims allowed separately by $\S 63$ (a) (4), may fall under $\S 63$ (a) (1)'s denial of interest. See 3 Collrer IfI 63.23-24. Post-bankruptcy interest on claims to which $\$ \$ 63(2)(1)$ and (a) (5) do not apply presumably are covered by the common-law rule as adopted by American courts. See Sexton v. Dreyfus, 219 U.S. 339 (1911).

5. Ibid; In re Berrian, 3 Fed. Cas. 283, No. 1351 (S.D.N.Y. 1873). The rule is also applied in bank liquidations, Merrill v. National Bank, 173 U.S. 131 (1899); Taylor v. Picher, 13 F. Supp. 857 (D. Me. 1936), aff'd per curiam, 87 F.2d 735 (1st Cir. 1937) ; cf. Ticonic Nat'l Bank v. Sprague, 303 U.S. 406 (1938), in equity receiverships, American Iron and Steel Mfg. Co. v. Seaboard Air Line Ry., 233 U.S. 261 (1914); Thomas v. Western Car Co., 149 U.S. 95 (1893), and in general assignments for the benefit of creditors, In the Matter of Pavone Textile Corp., 302 N.Y. 206, 97 N.E.2d 755 (1951), aff'd sub nom. United States v. Bloom, 342 U.S. 912 (1952).

6. New York v. Saper, 336 U.S. 328 (1949). Under the present Bankruptcy Act, as originally promulgated, tax claims were given preferential treatment. Contrary to the practice for ordinary debts, an affirmative duty was imposed upon the trustee to ascertain the amount of taxes due and to obtain an order from the court for payment. $\$ 57(\mathrm{n}), 30$ STAr. 561 (1898). In addition, taxes were given absolute priority. $\$ 64,30$ STAT. 563 (1898). Because these sections eliminated any administrative inconvenience, post-bankruptcy interest was allowed. In re Kallak, 147 Fed. 276 (D.N.D. 1906). The Supreme Court found a congressional intent to alter the treatment of tax claims in amendments to the Bankruptcy Act requiring taxes to be proved like ordinary debts and reducing them to the fourth priority. 52 STaT. 867, 874 (1938), 11 U.S.C. $\S \S 93(\mathrm{n}), 104$ (1952), New York v. Saper, supra. But see note 38 infra.

7. 342 U.S. 912 (1952), affirming per curiam 189 F.2d 876 (4th Cir. 1951). See also New York v. Feinberg, 204 F.2d 502 (2d Cir. 1953) (tax claims); Meinhard, Greef \& Co. v. Brown, 199 F.2d 70 (4th Cir. 1952) (secured creditors). Contra, In re Lexington Homes, Inc., 94 F. Supp. 482 (D.N.J. 1950) (tax claims). The rule has also been extended into arrangement proceedings under Chapter XI. Massachusetts v. Thompson, 190 F.2d 10 (1st Cir. 1951), cert. denied, 342 U.S. 918 (1952) ; United States v. General Engineering \& Mfg. Co., 188 F.2d 80 (8th Cir. 1951), aff'd per curiam, 342 U.S. 912 (1952). Dicta in New York v. Feinberg, supra at 502, and Meinhard, Greef \& Co. v. Brown, supra at 74, implied that the rule should encompass all claims prosecuted under Chapter X. For discussion of the tax cases, see Schwartz, Post-Bankruptcy Interest and Penalties Jurisdiction of the Bankruptcy Court, 30 REF. J. 88 (1956). 
interest had been regularly allowed in reorganizations prior to the enactment of Chapter $\mathrm{X}, 8$ which is silent on the point, and despite the fact that the typically extended duration of the proceedings makes interest especially significant. ${ }^{9}$

In the recent case of In re Inland Gas Corp., the Sixth Circuit applied Edens to interest due ordinary creditors. ${ }^{10}$ Thirty years before Inland, American Fuel \& Power Company, a parent of Kentucky Fuel Gas Corporation and Inland Gas Corporation, planned a new pipeline to the Detroit area to avoid financial collapse of the American system. ${ }^{11}$ Since this project jeopardized its monopoly in the area, Columbia Gas \& Electric Company aborted the program by acquiring control of the American group and effecting institution of liquidation proceedings against all three corporations. ${ }^{12}$ Held to violate section seven of the Clayton Act, ${ }^{13}$ Columbia's conduct forced subordination of its claims to all other

8. Consolidated Rock Products Co. v. Du Bois, 312 U.S. 510 (1941); In re Deep Rock Oil Corp., 113 F.2d 266 (10th Cir.), cert. denied, 311 U.S. 699 (1940); In re Minnesota \& Ontario Paper Co., SEC Reorg. Release No. 33 (Aug. 1, 1940). But see Group of Institutional Investors v. Chicago, M., St. P. \& Pac. R.R., 318 U.S. 523 (1943).

9. Of the forty-three Chapter X proceedings in which the SEC participated in 1957, petitions had been filed as follows; 1934-2; 1935-3; 1938-1; 1939-1; 1941-2; 1942-1; $1944-1$; $1945-1$; 1946-1; 1947-2; 1948-2; 1949-4; 1950-1; 1951-2; 1952-1; 1953-2; 1954-3; 1955-2; 1956-8; 1957-3. See SEC AnNual Rep. 232 (1957). See also Billyou, $A$ Decade of Corporate Reorganization under Chapter X, 49 CoLUm. L. Rev. 456, 495 n.267 (1949). For data on railroad reorganizations, see Dembitz, Progress and Delay in Railroad Reorganizations since 1933, 7 LAW \& Contexs. Prob. 393 (1940).

Frequently, claims to post-petition interest exceed principal in amount. See, e.g., Petition for Certiorari by Paul Kern, p. 5, Kern v. Williamson, 355 U.S. 838 (1957) (bond principal, $\$ 2,778,600$; post-petition interest, $\$ 4,217,992)$.

10. 241 F.2d 374 (6th Cir.), cert. denied, 355 U.S. 838 (1957). For a complete history of the Inland reorganization, see In the Matter of Inland Gas Corp., 217 F.2d 207 (6th Cir. 1954) ; In re Inland Gas Corp., 211 F.2d 381 (6th Cir.), cert. denied, 348 U.S. 840 (1954) ; In re Inland Gas Corp., 208 F.2d 13 (6th Cir. 1953) ; In re Inland Gas Corp., 187 F.2d 813 (6th Cir. 1951); Columbia Gas \& Elec. Corp. v. United States, 151 F.2d 461 (6th Cir. 1945), cert. denied, 329 U.S. 737 (1946) ; In re American Fuel \& Power Co., 122 F.2d 223 (6th Cir. 1941) ; Hamilton Gas Co. v. Inland Gas Corp., 102 F.2d 131 (6th Cir. 1939).

11. Columbia Gas \& Elec. Corp. v. United States, supra note 10, at 464.

12. Id. at 469 . The Inland proceedings began as an equity receivership. Although a reorganization device, equity receivership was in form a liquidation. A sale of assets occurred outside the court, and the creditors received new securities from the purchaser. Consequently, post-bankruptcy interest was generally denied. American Iron and Steel Mfg. Co. v. Seaboard Air Line Ry., 233 U.S. 261 (1914); Thomas v. Western Car Co., 149 U.S. 95 (1893). In contrast, Chapter $X$ reorganization is designed to avoid winding up, sales of assets and distribution of proceeds. In re Minnesota \& Ontario Paper Co., SEC Reorg. Release No. 33 (Aug. 1, 1940); see also 6 ColLIER If 0.04[2]; Glenn, The Basis of the Federal Receivership, 25 Colum. L. Rev. 434 (1925).

13. In re American Fuel \& Power Co., 122 F.2d 223 (6th Cir. 1941). Section 7 provides: "No corporation ... shall acquire ... the whole or any part of the stock or other share capital ... of another corporation where ... the effect of such acquisition may be substantially to lessen competition, or to tend to create a monopoly ...." 38 STAT. 731 (1914), as amended, 15 U.S.C. § 18 (1952). 
creditors and equity interests. ${ }^{14}$ Nevertheless, the Inland court disapproved a reorganization plan providing for payment of post-bankruptcy interest to unsubordinated creditors. In so doing, it enabled Columbia either to participate in a reorganized company or to share in liquidation of the old system. ${ }^{15}$

Following Edens, Inland is based on the "general rule" that interest ceases to accrue after the petition in bankruptcy. ${ }^{16}$ But since post-bankruptcy interest is allowed where creditors' substantive rights outweigh the inconvenience of recomputation, such a formulation is accurate only in so far as it ignores all 'relevant exceptions. When a bankrupt estate proves solvent, for example, interest to the date of the last liquidating dividend is paid before any return is made to the debtor. ${ }^{17}$ Similarly, a secured creditor receives post-bankruptcy interest to the extent his security exceeds the amount of his principal claim.18

14. Columbia Gas \& Elec. Corp. v. United States, 151 F.2d 461 (6th Cir. 1945). Originally, Columbia's claims had been rejected in a suit to which it was not a party. In re American Fuel \& Power Co., 122 F.2d 223 (6th Cir. 1941).

Inland was the only corporation of the American system with valuable assets, and bonds of American and Kentucky had been sold to the public on the faith of its pledged stock. Consequently, bondholders of American and Kentucky were considered "quasi creditors" of Inland. Since claims may be subordinated below debts of any rank, Columbia Gas \& Elec. Corp. v. United States, supra; cf. Prudence Realization Corp. v. Geist, 316 U.S. 89 (1942), these creditors became entitled to share in Inland's assets prior to Columbia's direct claims. In re Inland Gas Corp., 187 F.2d 813 (6th Cir. 1951). See also Taylor v. Standard Gas \& Elec. Corp., 306 U.S. 307 (1939); Israels, The Implications and Limitations of the "Deep Rock" Doctrine, 42 CorvM. L. Rev. 376 (1942).

Although the antitrust laws provide their own sanctions, a bankruptcy court may subordinate creditors whose conduct violates those statutes. See Pepper v. Litton, 308 U.S. 295 (1939). Otherwise, subordination would be restricted to less flagrant wrongdoers. Columbia Gas \& Elec. Corp. v. United States, supra at 469-70.

15. $241 \mathrm{~F} .2 \mathrm{~d}$ at 379.

16. Id. at 381. Actually, Inland is based on both Edens and New York v. Saper, 336 U.S. 328 (1949). See text at note 6 supra. The transmutation of an administrative practice into a substantive rule stems from references to the "general rule" by the Supreme Court in the context of ordinary bankruptcy. See, e.g., Sexton v. Dreyfus, 219 U.S. 339 (1911).

Often described as "ceasing to accrue" or "stopping" with the petition, see, e.g., New York v. Saper, supra at 330, post-bankruptcy interest may more accurately be portrayed as "suspended." See Sword Line, Inc. v. Industrial Comm'r, 212 F.2d 865, 872 (2d Cir.) (dissenting opinion), cert. destied, 348 U.S. 830 (1954). This formulation accords with the allowance of interest under the so-called "exceptions." See notes 17-19 infra and accompanying text. See also Johnson v. Norris, 190 Fed. 459 (5th Cir. 1911) ; Hanson, supra note 1, at 1086; Notes, 54 CoLum. L. Rev. 1293 (1954), 30 N.Y.U.L. Rev. 716 (1955).

17. Coder v. Arts, 213 U.S. 223 (1909); Miles Corp. v. Lindel, 107 F.2d 729 (Sth Cir. 1939); In re Norcor Mfg. Co., 36 F. Supp. 978 (E.D. Wis. 1941).

18. In re Macomb Trailer Coach, Inc., 200 F.2d 611 (6th Cir. 1952), cert. dcnied, 345 U.S. 958 (1953); Kagan v. Industrial Washing Mach. Corp., 182 F.2d 139 (1st Cir. 1950) ; In re Gotham Can Co., 48 F.2d 540 (2d Cir. 1931) ; cf. Beecher v. Leavenworth State Bank, 192 F.2d 10, 14 (9th Cir. 1951). This exception apparently honors a secured creditor's contractual rights in his security. See People's Homestead Ass'n v. Bartlette, 33 F.2d 561 (5th Cir. 1929) (allowing interest to date of sale of the mortgaged property where the proceeds covered principal and interest). 
Even if the security is not of greater value than the claim, return on collateral held by a secured creditor is applied to post-petition interest. ${ }^{19}$ Moreover, section sixty-three, limiting provable claims and denying post-petition interest to certain debts in ordinary bankruptcy, is expressly inapplicable in corporate reorganizations. ${ }^{20}$ Section 196, in contrast, commands broad judicial discretion in allowing claims prosecuted under Chapter $\mathrm{X} .{ }^{21}$ The status of interest accruing after a reorganization petition should, therefore, be governed by administrative and equitable considerations rather than simple application of a general rule neither general nor rule. ${ }^{22}$

Administrative factors dictating denial of post-petition interest in ordinary bankruptcy are absent in corporate reorganizations. Chapter $X$ reorganization plans ordinarily enable the debtor to continue business in a revitalized corporate structure. ${ }^{23}$ Only at consummation of the plan are enforceable creditor rights in the reorganized company established. Consequently, a single compu-

19. Sexton v. Dreyfus, 219 U.S. 339 (1911) (based on aversion to allowing debtor to profit by court-imposed delay) ; Pacific States Corp. v. Hall, 166 F.2d 668 (9th Cir. 1948) (dictum); see In re E. W. Hays \& Co., 12 F. Supp. 130 (W.D. Ky. 1935).

To prevent abuse where security will not cover both principal and post-petition interest, a creditor may not apply the proceeds first against interest. 3 CoLLIER $\llbracket 63.16(2)$.

20. Section $106(1)$ of Chapter $X$ includes ". . . all claims of whatever character against a debtor or its property ... whether or not such claims are provable under section 63 of this Act ..." 52 STAT. 883 (1938), 11 U.S.C. $\$ 506(1)$ (1952). As a matter of judicial construction, "claims" in reorganization encompass all liabilities of the debtor. In re Plankinton Bldg. Co., 135 F.2d 273 (7th Cir. 1943); see In re International Ry., 95 F. Supp. 140 (W.D.N.Y. 1949) (including a city's unliquidated claim against the debtor for future cost of removing trolley tracks).

21. "[T] he judge shall prescribe the manner in which and fix a time within which the proofs of claims of creditors ... may be filed and allowed. Objections by any party in interest to the allowance of any such claims or interests shall be heard and summarily determined by the court." 52 STAT. 893 (1938), 11 U.S.C. § 596 (1952).

22. "Under the general rule of law, the debtor is required to pay interest up to the time he pays his debt." Johnson v. Norris, 190 Fed. 459, 463 (5th Cir. 1911), cert. denied, 232 U.S. 723 (1914). One commentator suggests that the "general rule" is really the exception and that interest should be allowed unless administratively inconvenient. 3 COLlIER $\{$ 63.16. The formulation, however, is more than a problem of semantics. The Inland court, for instance, finding no precedent for an "exception," felt controlled by the "general rule." 241 F.2d at 381-82.

23. Unlike ordinary bankruptcy, reorganization is essentially a rehabilitative rather than a liquidation procedure. See In re Prudence Bonds Corp., 77 F.2d 328 (2d Cir.), cert. denied, 296 U.S. 584 (1935). But a reorganization plan may provide for liquidation and dissolution. Country Life Apartments, Inc. v. Buckley, 145 F.2d 935 (2d Cir. 1944); In re V. Loewer's Gambrinus Brewery Co., 141 F.2d 747 (2d Cir. 1944); cf. Fidelity Assurance Ass'n v. Sims, 318 U.S. 608 (1943) (petition in Chapter X not filed in good faith where no chance of reorganization exists and liquidation is the only object). See also Cary, Liquidations of Corporations in Bankruptcy Reorganization, 60 HARv. L. Rev. 173 (1946). Under certain circumstances, $\$ \$ 236-38$ dictate dismissing a reorganization before a plan has been evolved and instituting ordinary bankruptcy proceedings. 52 STAT. $899-900$ (1938), as amended, 11 U.S.C. \$\$ 636-38 (1952). 
tation is all that is required whether or not post-bankruptcy interest is allowed. ${ }^{24}$ Nor is recomputation necessary even if, as in Inland, a sale of the old company's assets and dissolution of its corporate form is contemplated by the plan. ${ }^{25}$

Thus unsupported by considerations of administrative expediency, Inland's denial of post-petition interest also contradicts the rationale of equitable subordination. ${ }^{26}$ Triggered by illegal or unfair conduct, subordination postpones the offending creditor's participation in a debtor's estate until full satisfaction of the claims of prejudiced creditors and shareholders. ${ }^{27}$ Admittedly, an inflexible rule universally denying interest would allow full legal compensation irrespective of loss of interest. But the unsubordinated creditors of the American system have been deprived of the use of capital for twenty-seven years of reorganization proceedings. $^{28}$ And since their principal claims would have exhausted the

24. See In re Minnesota \& Ontario Paper Co., SEC Reorg. Release No. 33 (Aug. 1, 1940). See also 6 CoLlier $\mathbb{1}$ 11.13. Allowing interest to the date of payment may be impractical because the delay intervening between proposal and consummation of the plan might necessitate a readjustment in relative participations. See Consolidated Rock Products Co. v. Du Bois, 312 U.S. 510, 514, 527 (1941) (allowing post-petition interest to date of the plan). But see note 39 infra.

Originally, the ICC allowed post-bankruptcy interest in railroad reorganizations. Denver \& R.G.W.R.R. Reorganization, 233 I.C.C. 515 (1939) ; Spokane Int'l Ry. Reorganization, 228 I.C.C. 387 (1938). Recently, however, relying on Group of Institutional Investors v. Chicago, M., St. P. \& Pac. R.R., 318 U.S. 523 (1943), it has denied such interest to secured creditors with deficiency claims. Florida East Coast Ry. Reorganization, 282 I.C.C. 81 (1951). Institutional Investors, based on a case involving a bank liquidation, Ticonic Nat'l Bank v. Sprague, 303 U.S. 406 (1938), has thus become the foundation for disallowing interest to secured creditors with deficiency claims in Chapter X.

However, this denial may be particularly inappropriate in Chapter $X$. If the security is a wasting asset, it will be constantly diminished by conversion into free assets. Since the secured creditor cannot foreclose on his security during reorganization, he will be unable to protect his preferred position. Such a creditor seems particularly deserving of post-petition interest on a deficiency claim. In re Minnesota \& Ontario Paper Co., supra. See Note, 50 Yale L.J. 144 (1940).

25. Liquidation in this instance follows consummation of the plan rather than filing of the petition. See note 23 supra.

26. "Subordination is a means of regulating distribution results . . . by adjusting the order of creditors' payments to the equitable levels of their comparative claim positions ... [I]ts fundamental aim is to undo or to offset any inequity in the claim position of a creditor that will produce injustice or unfairness to other creditors . ..." In re Kansas City Journal-Post Co., 144 F.2d 791, 800 (8th Cir. 1944). See also Prudence Realization Corp. v. Geist, 316 U.S. 89 (1942).

Construing Inland narrowly, the trustee's amended plan allows post-bankruptcy interest to subordinated creditors prior to the payment of such interest to senior bondholders. In the Matter of Inland Gas Corp., SEC Reorg. Release No. 109 (May 1, 1958) (disapproving this allowance as unfair).

27. Taylor v. Standard Gas \& Elec. Co., 306 U.S. 307 (1939); In re Deep Rock Oil Corp., 113 F.2d 266 (10th Cir.), cert. denied, 311 U.S. 699 (1940).

In Inland, the claims of Columbia and of the unsubordinated creditors were based on the same securities.

28. See note 10 supra. Interest is generally considered compensation for the use of capital rather than a penalty for delay in payment. Note, 95 U. PA. L. REv. 553, 555 
system's assets if the proceedings had been more expeditiously conducted, ${ }^{29}$ denial of interest seems an anomalous implementation of subordination doctrine. ${ }^{30}$ For it allows Columbia to benefit from the return on capital invested by the very parties whom its illegal conduct injured. ${ }^{31}$

In comparable fashion, the Inland approach ignores the thrust of the absolute priority rule. Adopted to prevent controlling shareholders from retaining interests in a debtor corporation to the detriment of creditors with outstanding claims, ${ }^{32}$ the rule currently commands full compensation to senior creditors before any participation is permitted juniors. ${ }^{33}$ Just as preferred stockholders

(1947). But if excessive, it may become a penalty which is disallowed on government claims by $\$ 57(j)$ of the Bankruptcy Act, 52 STAT. $\$ 67$ (1938), as amended, 11 U.S.C. $\$$ 93(j) (1952), District of Columbia v. Greenbaum, 223 F.2d 633 (D.C. Cir. 1955), and by case law on all other claims, see Vanston Bondholders Protective Comm. v. Green, 329 U.S. 156 (1946). For the applicability of $\$ 57(j)$ in Chapter X, see note 41 infra. Moreover, a covenant to pay interest upon interest in the event of default is void as against "equitable principles" of bankruptcy administration regardless of its validity under state law. Vanston Bondholders Protective Comm. v. Green, supra.

Vanston did not decide whether a covenant to compound interest is void under federal law or whether its validity would be determined by applicable state law. Some federal courts had previously distinguished between interest and compound interest. See, e.g., American Brake Shoe \& Foundry Co. v. Interborough Rapid Transit Co., 26 F. Supp. 954 (S.D.N.Y. 1939). But since compound interest differs from interest on interest only in degree, it should fall under the equitable principles of Vanston. See Transbel Inv. Co. v. Roth, 36 F. Supp. 396, 398-99 (S.D.N.Y. 1940).

If Vanston is inapplicable, compound interest presents a difficult conflicts problem. If a large bond indenture is executed in one state but the corporation's primary place of business is in another and the secured assets are in a third while products are sold in all forty-eight, the state of most significant contacts will be difficult to determine. See Vanston Bondholders Protective Comm. v. Green, supra; cf. concurring opinion of Mr. Justice Frankfurter, id. at 167.

29. 241 F.2d at 379.

30. See, generally, Clark, Interest on Clains in Receivership Proceedings, 19 MIcH. L. Rev. 35 (1920).

31. Inland may also limit an equity court's power to subordinate claims. Whether the district court based its disallowance of interest on equitable grounds or the "general rule" is not clear. See Transcript of Proceedings, March 8, 1956, pp. 46-50, In re Inland Gas Corp., 241 F.2d 374 (6th Cir. 1957). But since the Sixth Circuit assumed that the "general rule" controlled, subordination is effectively limited to principal. In contrast, the Supreme Court has described the power of a bankruptcy court to subordinate claims as "complete." Sampsell v. Imperial Paper \& Color Corp., 313 U.S. 215, 219 (1941). See also note 14 supra; In re Deep Rock Oil Corp., 113 F.2d 266 (10th Cir.), cert. denied, 311 U.S. 699 (1940) (allowing post-bankruptcy interest before participation of subordinated creditors).

32. Northern Pac. Ry. v. Boyd, 228 U.S. 482 (1913) (equity receivership) ; see Case v. Los Angeles Lumber Products Co., 308 U.S. 106 (1939) (absolute priority an aspect of the "fair and equitable" requirement of Chapter $\mathrm{X}$ ); see also 2 Dewing, Financial Policy of Corporations 1299-334 (5th ed. 1953).

33. Consolidated Rock Products Co. v. Du Bois, 312 U.S. 510 (1941); In the Matter of 620 Church Street Bldg. Corp., 299 U.S. 24 (1936); In re Day \& Meyer, Murray \& 
are entitled to unpaid dividends accumulating subsequent to bankruptcy although such payments eliminate junior shareholders from the reorganized company, ${ }^{34}$ senior creditors appear to deserve recognition of their equivalent contract right to post-petition interest. ${ }^{35}$ True, junior creditors may suffer from the delay of reorganization if senior creditors are paid interest exceeding the return on the estate's capital during Chapter $\mathrm{X}$ proceedings. ${ }^{30}$ But if interest is denied, capital invested by senior creditors may produce a return accruing only to junior interests. Since either alternative may prejudice one group while benefiting the other, absolute priority dictates that contract precedence include claims to post-bankruptcy interest. ${ }^{37}$

Young, Inc., 93 F.2d 657 (2d Cir. 1938). Full compensation encompasses more than recognition of a claim's face amount; "provision must be made for the entire bundle of rights" which a class surrenders. Consolidated Rock Products Co. v. Du Bois, sutpra at 528. Thus, allowance must be made for such rights as date of maturity or position as lienholder. See Note, 18 N.Y.U.L.Q. REv. 399, 464 (1941).

34. In re Deep Rock Oil Corp., 113 F.2d 266 (10th Cir.), cert. denied, 311 U.S. 699 (1940). See also Central States Elec. Corp. v. Austrian, 183 F.2d 879 (4th Cir. 1950), cert. denied, 340 U.S. 917 (1951); Petition of Portland Elec. Power Co., 162 F.2d 618 (9th Cir.), cert. denied, 332 U.S. 837 (1947).

35. Consolidated Rock Products Co. v. Du Bois, 312 U.S. 510 (1941) (post-petition interest allowed and entitled to the same priority as the principal claim). Although interferences with contract rights causing inconvenience in reorganization have been sanctioned by the Supreme Court, the rights involved in such cases were classified merely as remedial. Kuehner v. Irving Trust Co., 299 U.S. 445 (1937) (landlord's right to stipulated damages for future rental liability); Continental I1l. Nat'l Bank \& Trust Co. v. Chicago, R. I. \& Pac. Ry., 294 U.S. 648 (1935) (pledgee's power of sale). But sec Guaranty Trust Co. v. Henwood, 86 F.2d 347 (8th Cir. 1936), cert. denied, 300 U.S. 661 (1937) (right of trustee under an indenture to accelerate maturity upon insolvency is substantive).

36. Senior creditors causing delay in order to profit from a contractual interest rate exceeding that prevailing in the market should, of course, not be allowed to benefit from such activity. See Thomas v. Western Car Co., 149 U.S. 95, 116 (1893) (disallowing interest for "extortionate delays"); Georgia, F. \& A.R.R. v. Bankers Trust Co., 170 F.2d 733 (5th Cir. 1948) (creditor may lose interest claim by obstructive conduct).

37. Consolidated Rock Products Co. v. Du Bois, 312 U.S. 510 (1941); see In re Lexington Homes, Inc., 94 F. Supp. 482 (D.N.J. 1950) (absolute priority compels payment of post-bankruptcy interest on tax claims in Chapter X). But when extending the English rule to tax claims under Chapters $X$ and XI, courts have usually avoided the mandate of absolute priority by either ignoring its applicability, United States v. Edens, 189 F.2d 876 (4th Cir. 1951), aff'd per curiam, 342 U.S. 912 (1952) ; see Massachusetts v. Thompson, 190 F.2d 10 (1st Cir. 1951) ; cf. dissenting opinion, id. at 11, or by recognizing priorities only as of the petition date, New York v. Feinberg, 204 F.2d 502 (2d Cir. 1953). See 66 STAr. 433,11 U.S.C. $\$ 766(1952)$ (eliminating fair and equitable requirement from Chapter XI).

Where interest is not contractually stipulated, it has been allowed as damages for detention of the debt. New York Trust Co. v. Detroit, T. \& I. Ry., 251 Fed. 514 (6th Cir. 1918) ; Spring Coal Co. v. Keech, 239 Fed. 48 (4th Cir. 1916) (dictum). Such interest is granted in ordinary bankruptcy where the estate proves solvent. See American Iron and Steel Mfg. Co. v. Seaboard Air Line Ry., 233 U.S. 261 (1914). 
Like the Inland decision it fostered, Edens should be discarded. The holding on which Edens was based, applying the English rule to tax claims in ordinary bankruptcy because of a legislative intent more presumed than demonstrated, ${ }^{38}$ may be justified by administrative convenience ${ }^{39}$ and possible government power to recoup post-petition interest after discharge. ${ }^{40}$ But neither rationale is relevant to tax claims under Chapter $X .{ }^{41}$ If the rule should be applied to taxes owed at the beginning of reorganization proceedings to protect creditors from government acquisition of a disproportionate share of a debtor's estate, ${ }^{42}$ such a decision belongs more properly to the legislature than the courts. Since Congress has altered the priority of tax claims only in ordinary

38. New York v. Saper, 336 U.S. 328 (1949); see note 6 sttpra. Nothing in the legislative history of the amendments warranted the finding that Congress intended to assimilate tax claims to ordinary debts for purposes of the rule. Saper v. New York, 168 F.2d 268, 270-71 (2d Cir. 1948). Moreover, their present fourth priority still differentiates such claims from private unsecured debts. And a proposed amendment explicitly disallowing interest was never passed. See Note, 58 Y ALE L.J. 982, 990 n.36 (1949). Congress, nevertheless, has implicitly approved Saper. H.R. REP. No. 2320, 82d Cong., $2 d$ Sess. 8 (1952).

39. See 61 Harv. L. REv. 354 (1948). Recomputation will be required when tax claims bear different interest rates. If historically impracticable, recomputation would not appear to create undue inconvenience today.

40. Under $\S 17$ of the Bankruptcy Act, tax claims are not dischargeable. 30 STAT. 550 (1898), as amended, 11 U.S.C. \& 35(a) (1952). Whether post-bankruptcy interest can be recovered as part of a nondischargeable tax claim is uncertain. Compare Sword Line, Inc. v. Industrial Comm'r, 212 F.2d 865 (2d Cir.), cert. denied, 348 U.S. 830 (1954) (denying recovery), with 212 F.2d at 870 (dissenting opinion); Note, 58 Y ALE L.J. 982 (1949). See also 54 Colum. L. Rev. 1293 (1954), 30 N.Y.U.L. Rev. 716 (1955), 40 VA. L. REv. 937 (1954).

3 Coluner $\llbracket 63.16$ states that discharge does not affect a debt which is not provable and hence cannot destroy a claim to post-petition interest. See also Matter of Paley, 260 App. Div. 632, 23 N.Y.S.2d 407 (1st Dep't 1940) ; Matter of the Utica Pipe Foundry Co., 36 Am. Bankr. R. 217 (N.D.N.Y. 1916) (allowing interest on dividend originally withheld by trustee as preference).

41. Section 17 is inapplicable in Chapter X. 52 STAT. 899 (1938), 11 U.S.C. $\$ 628(1)$ (1952). See American Serv. Co. v. Henderson, 120 F.2d 525 (4th Cir. 1941). See also note 24 supra and accompanying text (lack of administrative inconvenience in Chapter X).

Section $57(j)$ provides in part: "Debts owing to the United States or to any state... as a penalty . . . shall not be allowed, except for the amount of the pecuniary loss sustained by the act, transaction ... and such interest as may have accrued on the amount of such loss according to law." 52 STAт. 867 (1938), as amended, 11 U.S.C. \$ 93(j) (1952). Congress has indicated that in ordinary bankruptcy accruing "according to law" means up to the date of petition. H.R. REP. No. 2320, 82d Cong., 2d Sess. 8 (1952). Although $\S 57(\mathrm{j})$ is probably applicable in Chapter X, 6 Collier $\llbracket 9.04$, at 2790-91 n.17, it merely restates whatever rule is otherwise relevant.

42. "Those most immediately concerned with administration of the [Bankruptcy] Act have frequently expressed dissatisfaction over the inroads taxes and interest thereon make in the fund available for creditors." New York v. Saper, 336 U.S. 328, 329 n.5 (1949). 
bankruptcy, ${ }^{43}$ it apparently has not intended to extend this safeguard to creditors claiming under Chapter X.

43. See note 6 supra. Compare $\$ 199$ of the Chandler Act, 52 STAT. 893 (1938), 11 U.S.C. $\S 599$ (1952) (first priority to United States tax claims), with $\S 77 \mathrm{~B}(\mathrm{e}), 48$ STAT. 911 (1934), as amended, 49 Stat. 965 (1935) (same); see Developments in the Law-Reorganization Under Section 77B of the Bankruptcy Act, 49 HARv. L. Rev. 1111, 1179 (1936).

Nor have tax priorities of state and other governmental subdivisions been altered by Chapter $\mathrm{X}$. See 6 CoLLIER I $9.13[3]$. 